\title{
Study of Contact Examination of the Teeth Automotive Gear and Its Numerical Analysis: A Literature Review
}

\author{
Sunil Padole ${ }^{1}$, Ravindra Pathak ${ }^{2}$ \\ ${ }^{1}$ Ph D Scholar, ${ }^{2}$ Associate Professor \\ Department of Mechanical Engineering, Medi-Caps University, Indore, India
}

\begin{abstract}
Gear tooth contact analysis is the subject of this review study, which includes a review and a comparative numerical analysis approach. In gear, working transmission error is investigated in both static and dynamic conditions. Transmission fault is a major cause of gearbox noise. The transmission error has been minimized as a result of a final gear manufacturing setting that has been proposed and analyzed. We attempt to address several numerical analytical methods of tooth contact analysis of a spiral bevel gear in this study, as well as a review of the FEM methodology and experimental prediction contact pattern in gear teeth. In this field of the overall contribution of the literature investigated, strengths, weaknesses are discovered. The potential missing and this study be used by other future studies is evaluated. The next steps for research are suggested. These next steps should address explicitly how the gaps and weaknesses will be corrected.
\end{abstract}

Keywords-Spiral bevel gear, Tooth contact analysis, Transmission error.

\section{I- INTRODUCTION}

F or transmitting motion and power from the engine to the wheel gear is used. Three complimentary characteristics of gear behavior under load are highlighted. The gear's elastic behavior. The point at which the pinion and the gear come into contact. The load is shared amongst the teeth that are in contact at the same time. Facing a problem of failure before the gear's expected life. The goal was to improve the transmission system's efficiency. Reduce noise and vibration during spiral bevel gear meshing in the workplace. Reduce the production lag time.

\section{II - SPUR AND HELICAL GEARS}

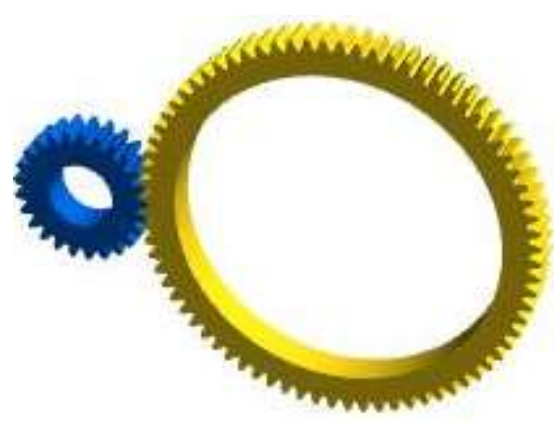

Fig.1-Spur Gear

This shows axes of gear are parallel to teeth. 


\section{International Journal of Innovations in Engineering and Science, www.ijies.net}

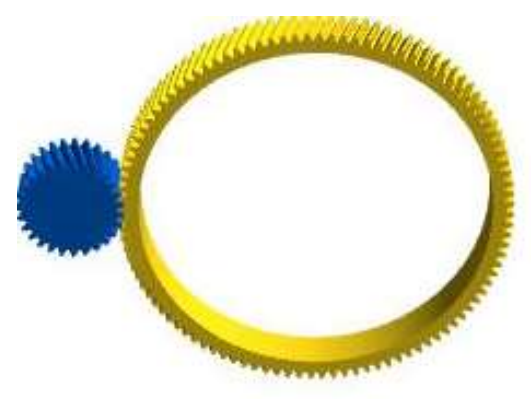

Fig.2-Helical Gear

This shows axes of gear are inclined to teeth.

Litvin et al. develop an analytical approach for kinematic inaccuracy in spiral bevel gear [1]. Drago R. and Mack J. tested the Heavy Lift Helicopter Endurance Test was completed with all engines running and one engine operating working at 95 percent of design loads [2]. Sasaoka identified the transmission error, a spur gear measurement approach has been devised at high speeds and loads [6]. Spur gear module 3.738 was used in an experiment using the Heidenhain 36000 line encoders corner contact to determine transmission error at various torques by Munro[9]. The Harmonic Analysis was done by Rao and Yoon of the helical gear of module 5 at various loads [10]. To discover dynamic transmission error, tangentially mounted accelerometers, and Laser torsional vibration meters were used to perform tooth contact analysis on a spur gear with 44,21 teeth. The transmission error and Sound Pressure Level were determined using experimental analysis with Load and Profile Error on a spur gear with the number of teeth of 55,34 [14]. For discovery transmission error, a spur gear with a module of 2 and two models with the same number of teeth of 24 is generated with CAD and tiff relief is studied at constant load [19]. Spur gear with the module of 3 and three pairs $(2,40)(41,53)(41,53)$ of teeth generated the computer programs by Podzharov et al. Tooth contact analysis of a high contact ratio has been obtained the low dynamic transmission error and static transmission error [22]. Helical gear of module 4.44 and pair with teeth of 34,32 performed experiment on Test Rig with considering Lead error and Profile modifications to the invention of Transmission error, Contact Stress and Sound Pressure Level [23]. Spur gear has been modeled and simulated with FEM calculation and KISSsoft software with Profile Correction shows an effect on a peak to peak transmission error [26]. Helical gear with the module of 3.5 number of teeth are $(49,36)$ and $(65,36)$ experiment with the same load at increased speed and same speed at increase load to result from
Transmission error increase with the increase of the input load, accurate at high speed [29].To find the maximum deflection, maximum bending stress, and stiffness of a helical gear with the module of 8 and number of teeth are 94,24. Ansys software was used to determine the maximum deflection, maximum bending stress, and stiffness [35]. Virtual marking compound thickness (VMCT) discrete triangular meshes, degree of refinement to obtain desired contact patterns, contact routes, and transmission mistakes are used in the spur gear of module 1, and teeth are 34,20. Spur gear with a tooth count of 75,25 was used in an experiment by Banodiya and Karma.. Use of defective and precise gear at a specific RPM to determine the transmission error (in rpm) [42]. ERN 460 encoders have been used to measure the torque on a spur gear with 21 teeth. Compare the results to those obtained using Matlab software by Kucera et al.[45]. Models of helical gears with 100 and 25 teeth were constructed and simulated by Narayanan in KISSsoft software using parameters such as end relief, helix angle error, profile crowning, and pressure angle to produce Stress distribution and line load distribution over the face width [50].

\section{III -SPIRAL GEARS}

Types of Bevel Gears are as follows

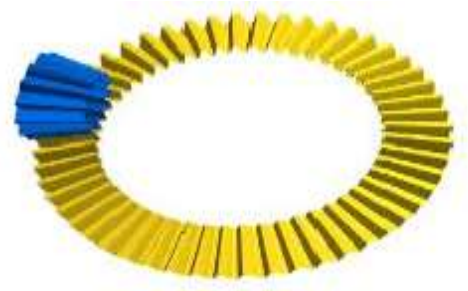

Fig.3-Straight Bevel Gear

This figure shows the mating gear axes are at 90 degrees. Teeth are straight.

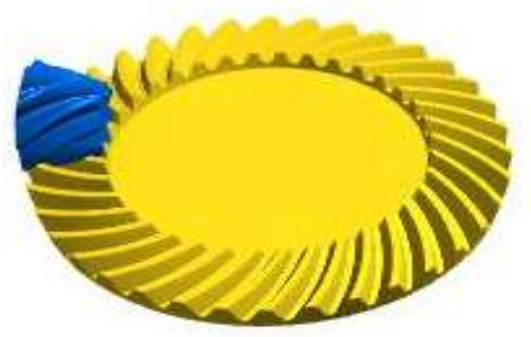

Fig.4-Spiral Bevel Gear

This figure shows the mating gear axes are at 90 degrees.

Teeth are curved in shape 
Vol. 6, No. 11, 2021, PP. 21-29

\section{International Journal of Innovations in Engineering and Science, www.ijies.net}

Due to improper Machine setting: Blank offset, Sliding base setting, Machine center to back, Machine root angle, Basic cradle angle, Basic radial, Ratio of roll variation.

Profile errors produce like crowning, Profile Crowing (Barreling), Pressure Angle Modification, Eccentric Profile Crowing,

Twist, Helix Angle Modification, Eccentric Crowing, Topological Modification.

\section{Types of Profile errors in Spiral Bevel Gear}
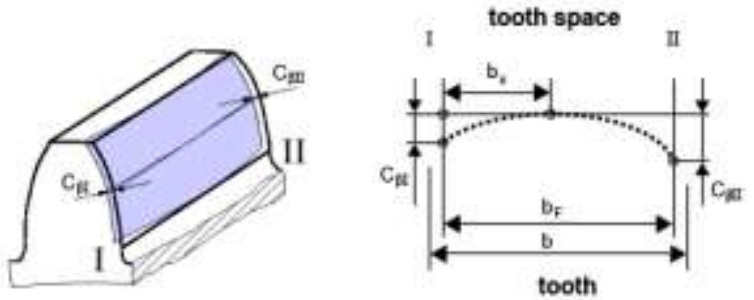

Fig.5-Crowning
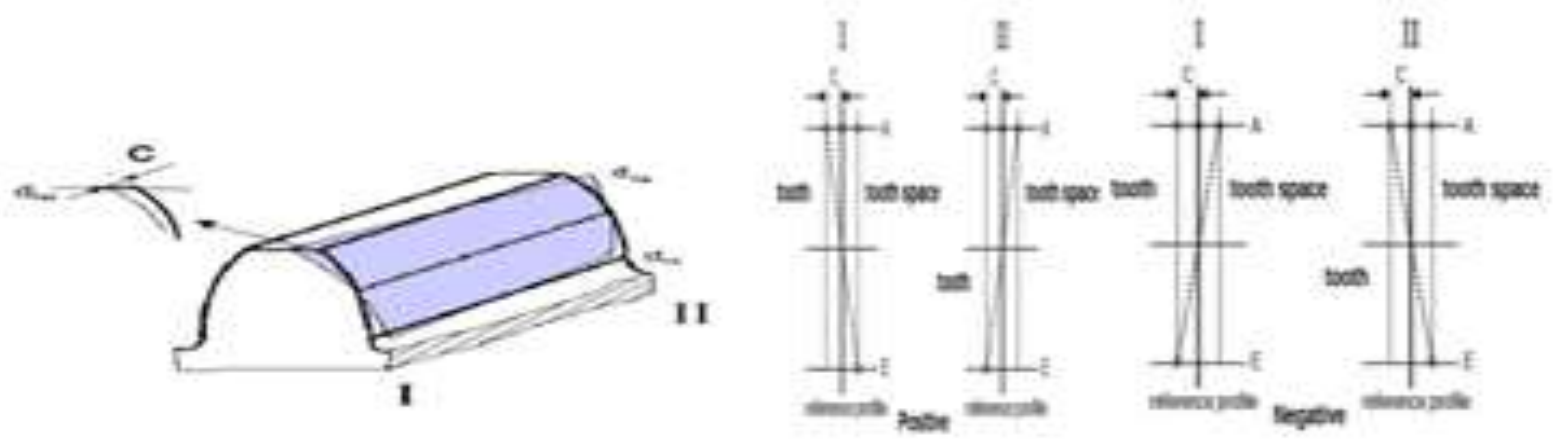

Fig.7- Twist

This shows surface deviation along with depth and width in Positive and Negative of teeth of the gear.
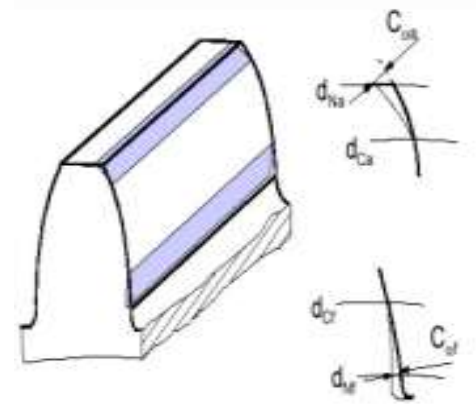

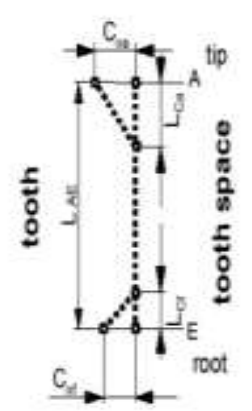

Fig.8 -Tip / Root Relief, Linear
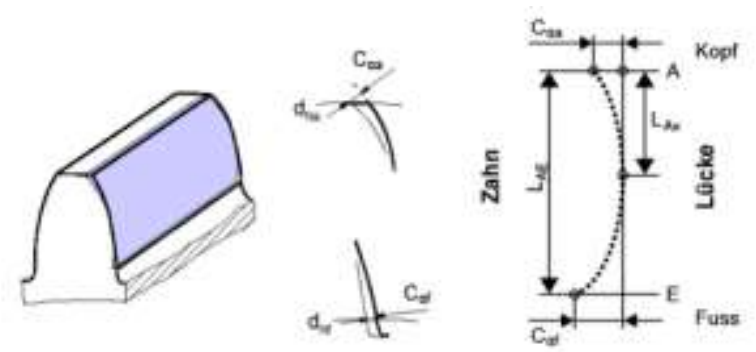

Fig.6- Profile crowning (Barreling)

This shows surface deviation along with the depth of teeth of the gear.

This shows surface deviation along the width of teeth of the gear 


\section{International Journal of Innovations in Engineering and Science, www.ijies.net}
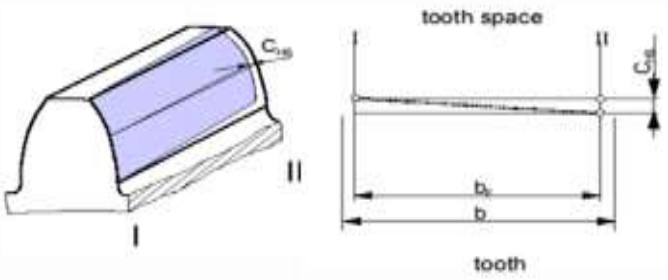

Fig.10 - Helix Angle Modification

This similarly shows helix angle correction as end relief. Surface deviation along the width of gear.

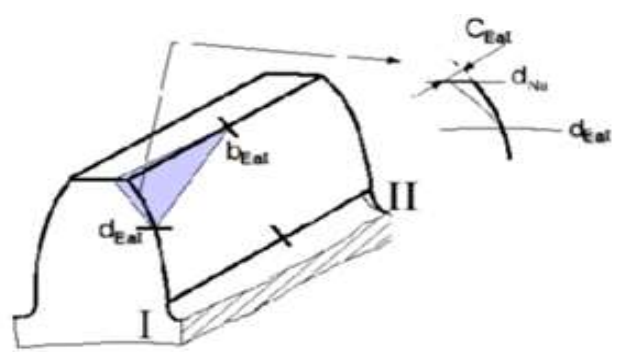

Fig.11 - Triangular End Relief
Surface deviation at End Relief of gear. Triangular surface area.

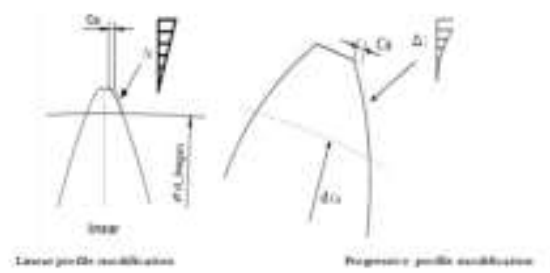

Fig. 12-Comparison of Linear and Progressive Profile Modification

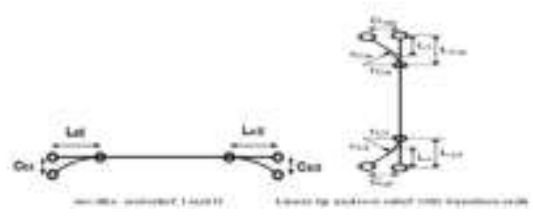

Fig. 13-Comparison of Arc like end relief and Linear tip and root relief with transition radii Profile Modification

Table 1-Comparative Numerical Analysis of Spiral Bevel Gear

\begin{tabular}{|c|c|c|c|c|}
\hline References & $\begin{array}{l}\text { Gear Size } \\
\text { (Module, No. of } \\
\text { teeth of Gear, } \\
\text { Pinion) } \\
\end{array}$ & Method & $\begin{array}{l}\text { Parameters } \\
\text { Considered }\end{array}$ & Crucial observation \\
\hline 1 & 40,20 & Analytical method & $\begin{array}{l}\text { Pinion and gear } \\
\text { eccentricity, axial } \\
\text { pinion/gear, } \\
\text { displacements }\end{array}$ & Kinematic error \\
\hline 2 & $\begin{array}{l}\text { Heavy Lift } \\
\text { Helicopter }\end{array}$ & $\begin{array}{l}\text { Endurance Test, } \\
\text { Dynamic Testing }\end{array}$ & $\begin{array}{l}\text { All Engine operating, } \\
\text { One engine In } \\
\text { operating }\end{array}$ & $\begin{array}{l}95 \text { percent of design loading, } \\
\text { Alternating stresses }\end{array}$ \\
\hline 3 & & $\begin{array}{l}\text { Direct Drive } \\
\text { Tester }\end{array}$ & $\begin{array}{l}\text { Under Load and } \\
\text { Speed }\end{array}$ & $\begin{array}{l}\text { Transmission error under load, } \\
\text { measuring the errors at operating } \\
\text { speeds, } 2 \text { methods for optical } \\
\text { encoders, and } 2 \text { methods for } \\
\text { torsional accelerometers }\end{array}$ \\
\hline 4 & 31,28 & $\begin{array}{l}\text { EPG test machine, } \\
\text { the mathematical } \\
\text { model }\end{array}$ & $\begin{array}{l}\text { Loaded tooth contact } \\
\text { Analysis, machine- } \\
\text { tool settings }\end{array}$ & $\begin{array}{l}\text { Kinematic errors and contact } \\
\text { patterns }\end{array}$ \\
\hline 5 & & $\begin{array}{l}\text { General } \\
\text { Formulation }\end{array}$ & Under Load & Load Shearing and TE \\
\hline 7 & $5,25,25$ & $\begin{array}{l}\text { Numerical and } \\
\text { experiment }\end{array}$ & Contact ratio & $\begin{array}{l}\text { Theoretical and actual contact } \\
\text { patterns }\end{array}$ \\
\hline 8 & $8.24,37,6$ & Analog Encoder, & Different torque & Simulation and Measurement of \\
\hline
\end{tabular}


Vol. 6, No. 11, 2021, PP. 21-29

International Journal of Innovations in Engineering and Science, www.ijies.net

\begin{tabular}{|c|c|c|c|c|}
\hline & & Optical Encoder & & Bearing Patterns,TE \\
\hline 11 & $6.5,44,13$ & & $\begin{array}{l}\text { Edge contact, } \\
\text { Negative Offset }\end{array}$ & Contact trace Lines, TE \\
\hline 12 & $4.83,33,9$ & $\begin{array}{l}\text { The computer } \\
\text { program for } \\
\text { simulation }\end{array}$ & $\begin{array}{l}\text { Machine-tool settings } \\
\text { and mean contact } \\
\text { point not known }\end{array}$ & Path of Contact Lines, TE \\
\hline 15 & $5.11,44,15$ & $\begin{array}{l}\text { Load, No Load, } \\
\text { Gleason T2000 }\end{array}$ & $\begin{array}{l}\text { Misalignment, } \\
\text { Different Load }\end{array}$ & $\begin{array}{l}\text { Contact Pattern, Contact } \\
\text { pressure, TE, Optimum } \\
\text { Condition, Stress }\end{array}$ \\
\hline 16 & $5.8,44,15$ & $\begin{array}{l}\text { Magnetic and } \\
\text { optical encoders, } \\
\text { numerical } \\
\text { simulations }\end{array}$ & Load $65,130 \mathrm{Nm}$ & TE \\
\hline 17 & $3.9,34,17$ & $\begin{array}{l}\text { Algorithm for a } \\
\text { geometrical and } \\
\text { kinematical } \\
\text { analysis }\end{array}$ & Hertz, Non-Hertz & $\begin{array}{l}\text { Contact patterns, TE, Max. } \\
\text { Pressure }\end{array}$ \\
\hline 18 & $5,50,17$ & $\begin{array}{l}\text { Computer } \\
\text { simulation }\end{array}$ & $\begin{array}{l}\text { Influence of machine } \\
\text { setting }\end{array}$ & $\begin{array}{l}\text { TE, the path of contact, contact } \\
\text { lines, }\end{array}$ \\
\hline 20 & $4.25,86,23$ & $\begin{array}{l}\text { Phoenix 800PG } \\
\text { Grinding }\end{array}$ & Machine tool-settings & TE, Contact Pattern \\
\hline 21 & $5,50,13$ & Computer program & Machine tool-settings & Path of contact, T.E. \\
\hline 24 & $5,50,13$ & Gleason Phoenix & Machine tool-settings & TE, contact pressure \\
\hline 25 & $5.5,26,16$ & $\begin{array}{l}0,50,100 \mathrm{Nm}, \\
\text { MATLAB }\end{array}$ & $\begin{array}{l}\text { Modified (pinion } \\
+0.026 \text { ), unmodified } \\
\text { experiment T.E. }\end{array}$ & $\begin{array}{l}\text { Meshing performance of } \\
\text { modified is better }\end{array}$ \\
\hline 27 & 35,40 & Light, heavy & $\begin{array}{l}\text { Effect of mean mesh } \\
\text { stiffness, khm2 } \\
\text { change }\end{array}$ & $\begin{array}{l}\text { Stiffness for the drive side has } \\
\text { more effect on the dynamic } \\
\text { response, vibration characteristic } \\
\text { for the heavily loaded case is far } \\
\text { better. }\end{array}$ \\
\hline 28 & $1.8,38,43$ & & Width,height,ratio, $\mathrm{x}, \mathrm{y}$ & TE, tooth face contact trace \\
\hline 30 & $4.941,36.12$ & Computer program & $\begin{array}{l}\text { Radial machine tool } \\
\text { setting variation, tilt } \\
\text { distance, roll ratio } \\
\text { variation, tilt and } \\
\text { swivel angles, head- } \\
\text { cutter profile radii, the } \\
\text { difference in head- } \\
\text { cutter radii }\end{array}$ & $\begin{array}{l}\text { Unbalanced separations, edge } \\
\text { contact, and considerable } \\
\text { transmission errors }\end{array}$ \\
\hline 31 & Bevel 2.9,19.42 & Simulation & $\begin{array}{l}\text { Shaft angle, the } \\
\text { mounting distance of } \\
\text { the crown }\end{array}$ & $\begin{array}{l}\text { The greater error increases } \\
\text { Transmission error }\end{array}$ \\
\hline 32 & $12.7,51,15$ & Simulation, Actual & $\begin{array}{l}\text { Machine setting } \\
\text { (grinding) }\end{array}$ & Value of profile is same \\
\hline 33 & Dump Truck & $\begin{array}{l}\text { Unload, load, test, } \\
\text { Analysis }\end{array}$ & Load increase & $\begin{array}{l}\text { Contact pattern change, } \\
\text { Comparison, deflection }\end{array}$ \\
\hline 34 & $6.5,60,46$ & & Original machine & Transmission error, the contact \\
\hline
\end{tabular}


Vol. 6, No. 11, 2021, PP. 21-29

International Journal of Innovations in Engineering and Science, www.ijies.net

\begin{tabular}{|c|c|c|c|c|}
\hline & & & setting, optimization & area \\
\hline 36 & $4,61,61$ & $\begin{array}{l}\text { Load, speed, NI } \\
\text { Labview }\end{array}$ & $\begin{array}{l}\text { Dynamic transmission } \\
\text { error test }\end{array}$ & Peak to Peak Transmission error \\
\hline 37 & $9,25,11$ & UG Software & $\begin{array}{l}\text { Radii of the } \\
\text { generating arcs of } \\
\text { circles, Coefficient }\end{array}$ & Transmission ratio error \\
\hline 39 & $2.6548,41,12$ & $\begin{array}{l}\text { The experiment of } \\
\text { actual SFT }\end{array}$ & $\begin{array}{l}\text { PSFT and actual SFT, } \\
\text { Position of pinion }\end{array}$ & $\begin{array}{l}\text { Transmission error and the } \\
\text { contact pattern }\end{array}$ \\
\hline 40 & $5.5,32,25$ & & $\begin{array}{l}\text { Assembly } \\
\text { misalignment }\end{array}$ & Contact area, transmission error \\
\hline 41 & $4,39,7$ & Experiment & Machine settings & LTCA \\
\hline 43 & & $\begin{array}{l}\text { Experiment, } \\
\text { Romax }\end{array}$ & $\begin{array}{l}\text { Static analysis, Modal } \\
\text { Analysis }\end{array}$ & $\begin{array}{l}\text { Deflection, von Mises } \\
\text { Stress, Moment along axes }\end{array}$ \\
\hline 44 & 30,10 & $\begin{array}{l}\text { FEA, Ansys14, } \\
\text { Experiment }\end{array}$ & Different Load, speed & $\begin{array}{l}\text { Max bending stresses, Max } \\
\text { Contact Stress, Transmission } \\
\text { efficiency }\end{array}$ \\
\hline 46 & $\begin{array}{l}2.5(30,32) \\
2(26,28) \\
\end{array}$ & $\begin{array}{l}\text { Loading } \\
\text { experimental }\end{array}$ & $\begin{array}{l}\text { Different Load, } \\
\text { assembly errors }\end{array}$ & RMS- DTE, \\
\hline 47 & $3.4884,47,11$ & $\begin{array}{l}\text { Load, Abaqus, } \\
\text { Masta, }\end{array}$ & $\begin{array}{l}\text { Misalignment, System } \\
\text { Deflection(Shell } \\
\text { stiffness, Bearing } \\
\text { Stiffness, Bearing } \\
\text { Location) }\end{array}$ & Contact pattern, Angular TE \\
\hline 48 & 34,11 & Load, Abaqus & Mesh frequency & $\begin{array}{l}\text { Angular TE, Mesh deflection, } \\
\text { Mesh force }\end{array}$ \\
\hline 49 & $3.9,65,23$ & & & HTE, PTE,RMS oscillation \\
\hline 51 & $6,46,15$ & $\begin{array}{l}\text { ANSYS, KISSsoft, } \\
\text { Test }\end{array}$ & Different Load & $\begin{array}{l}\text { Maximum bending stresses, } \\
\text { Transmission error }\end{array}$ \\
\hline 52 & $7,65,23$ & Simulation & $\begin{array}{l}\text { Sensitivity of gear to } \\
\text { Misalignment, } \\
\text { modified cutter for } \\
\text { pinion, gear }\end{array}$ & $\begin{array}{l}\text { Compare the contact paths of the } \\
\text { original gear and the changed } \\
\text { gear. }\end{array}$ \\
\hline 53 & $3.15,55,47$ & Simulation & $\begin{array}{l}\text { Machine tool setting } \\
\text { modification }\end{array}$ & Transmission error \\
\hline 54 & $\begin{array}{l}3,55,47 \\
3,48,43\end{array}$ & Simulation, Test & $\begin{array}{l}\text { Pinion and gear } \\
\text { rotation angle, } \\
\text { Misalignment }\end{array}$ & Loaded Transmission error \\
\hline 55 & $3.85,74,27$ & Numerical & Load, Meshing Point & Loaded Transmission error \\
\hline
\end{tabular}

\section{IV-CONCLUSION}

In spur gear profile errors like end relief, helix angle error, profile crowning, and pressure angle are considered in tooth contact analysis. Different methods are investigated for finding the transmission error with misalignment. Due to the effect of misalignment and loading changes occurring in contact pattern has been observed. System Deflection like Shell stiffness, Bearing Stiffness, Bearing Location is considered after applying load. In loaded tooth contact analysis mid-position of mesh gear is changed due to elasticity. In above, most of the literature survey found that experimental analysis is done. That result should be compared to the simulation result.

In the above profile error in spiral bevel gear has not been considered in tooth contact analysis, misalignment, and different load and unloading conditions. The change 


\section{International Journal of Innovations in Engineering and Science, www.ijies.net}

of material of gear and its comparison of tooth contact analysis has been considered for future study. A comparison of transmission error and contact pattern with and without profile hasn't been considered. The tooth contact analysis of hypoid gear hasn't been considered. The combination of profile error with misalignment at different loads is the research gap found in the investigated literature review. To find optimal torque at which peak to peak transmission error is low and contact ratio should be high. The use of KISSsoft software and experiment setup is recommended to find Transmission error, Contact pattern, Bending stress in the root area, Wear along the tooth flank, Safety against scuffing, Contact lines, Contact temperature, Single contact stiffness, Safety against tooth flank fracture in Tooth contact analysis.

\section{REFERECNCES}

[1] Litvin, F. L., Goldrich, R. N., Coy, J. J., \&Zaretsky, E. $V$. (1983). The precision of spiral-bevel gears.

[2] Drago, R., \& Mack, J. (1987). Development of a large, spiral bevel gear rotorcraft transmission. In 23rd Joint Propulsion Conference (p. 1839).

[3] Houser, D. R., \& Blankenship, G. W. (1989). Methods for measuring gear transmission error under load and at operating speeds. SAE transactions, 1367-1374.

[4] Fong, Z. H., \&Tsay, C. B. (1992). Kinematical optimization of spiral bevel gears.

[5] Gosselin, C., Cloutier, L., \& Nguyen, Q. D. (1995). A general formulation for the calculation of the load sharing and transmission error under load of spiral bevel and hypoid gears. Mechanism and Machine Theory, 30(3), 433-450.

[6] Sasaoka, S. (1997). Measurement technique for loaded gear transmission error (No. 970973). SAE Technical Paper.

[7] Falah, B., Gosselin, C., \&Cloutier, L. (1998). Experimental and numerical investigation of the meshing cycle and contact ratio in spiral bevel gears. Mechanism and machine theory, 33(1-2), 21-37.

[8] Gosselin, C., Guertin, T., Remond, D., \& Jean, Y. (2000). Simulation and experimental measurement of the transmission error of real hypoid gears under load. J. Mech. Des., 122(1), 109-122.

[9] Munrol, R. G., Palmer, D., \&Morrish, L. (2001). An experimental method to measure gear tooth stiffness throughout and beyond the path of contact. Proceedings of the Institution of Mechanical Engineers, Part C: Journal of Mechanical Engineering Science, 215(7), 793-803.

[10] Rao, S. S., \& Yoon, K. Y. (2001). Minimization of transmission error in helical gears. Proceedings of the Institution of Mechanical Engineers, Part C: Journal of Mechanical Engineering Science, 215(4), 447-459.
[11] Vogel, O., Griewank, A., \&Bär, G. (2002). Direct gear tooth contact analysis for hypoid bevel gears. Computer methods in applied mechanics and engineering, 191(36), 3965-3982.

[12] Litvin, F. L., Sheveleva, G. I., Vecchiato, D., GonzalezPerez, I., \& Fuentes, A. (2005). Modified approach for tooth contact analysis of gear drives and automatic determination of guess values. Computer Methods in Applied Mechanics and Engineering, 194(27-29), $2927-$ 2946.

[13] Tůma, J. (2006). Dynamic transmission error measurements. Engineering Mechanics, 13(2), 101 106.

[14] Davoli, P., Gorla, C., Rosa, F., Rossi, F., \&Boni, G. (2007). Transmission error and noise emission of spur gears. Gear Technology, 24(2), 34-38.

[15] Vimercati, M. (2007). Mathematical model for tooth surfaces representation of face-hobbed hypoid gears and its application to contact analysis and stress calculation. Mechanism and Machine Theory, 42(6), 668-690.

[16] De Vaujany, J. P., Guingand, M., Remond, D., \&Icard, $Y$. (2007). Numerical and experimental study of the loaded transmission error of a spiral bevel gear.

[17] Sheveleva, G. I., Volkov, A. E., \& Medvedev, V. I. (2007). Algorithms for analysis of meshing and contact of spiral bevel gears. Mechanism and Machine Theory, 42(2), 198-215.

[18] Simon, V. (2007). Computer simulation of tooth contact analysis of mismatched spiral bevel gears. Mechanism and Machine Theory, 42(3), 365-381.

[19] Tharmakulasingam, R., Alfano, G., \& Atherton, M. A. (2008). Reduction of gear pair transmission error with tooth profile modification.

[20] Xuemei, C., Zongde, F., Hao, X., \&Jinzhan, S. (2008). Design of pinion machine tool-settings for spiral bevel gears by controlling contact path and transmission errors. Chinese Journal of Aeronautics, 21(2), 179-186.

[21] Simon, V. (2008). Influence of tooth errors and misalignments on tooth contact in spiral bevel gears. Mechanism and Machine Theory, 43(10), 12531267.

[22] Podzharov, E., Syromyatnikov, V., Navarro, J. P. P., \& Navarro, R. P. (2008). Static and dynamic transmissin error in spur gears. The Open Industrial \& Manufacturing Engineering Journal, 1(1).

[23] Henriksson, M., \& Pang, Y. Y. (2009, January). Transmission error as gear noise excitation. In International Design Engineering Technical Conferences and Computers and Information in Engineering Conference (Vol. 49033, pp. 197-203).

[24] Simon, V. V. (2009). Design and manufacture of spiral bevel gears with reduced transmission errors.

[25] Yang, H., \& Zhang, Y. (2010, March). Meshing Simulation and Experimental Analysis of Transmission Error for Modified Spiral Bevel Gear. In 2010 


\section{International Journal of Innovations in Engineering and Science, www.ijies.net}

International Conference on Measuring Technology and Mechatronics Automation (Vol. 2, pp. 636-639). IEEE.

[26] Kissling, E. U. (2010). Effects of Profile Corrections on Peak-to-Peak Transmission Error. Gear Technology, 52-61.

[27] Yinong, L., Guiyan, L., \& Ling, Z. (2010). Influence of asymmetric mesh stiffness on dynamics of spiral bevel gear transmission system. Mathematical Problems in Engineering, 2010.

[28] Jiang, P., Liu, G. L., Zhang, R. T., \& Wang, C. Q. (2011). Quantitative Evaluation of Aero Spiral Bevel Gear Meshing Quality. In Applied Mechanics and Materials (Vol. 86, pp. 428-433). Trans Tech Publications Ltd.

[29] Shi, Q., Cheng, X. W., Guo, D., \& Shi, X. H. (2011). Theory and Experiment Study on Transmission Error of Gear System. In Key Engineering Materials (Vol. 450, pp. 341-344). Trans Tech Publications Ltd.

[30] Simon, V. V. (2011). Influence of tooth modifications on tooth contact in face-hobbed spiral bevel gears. Mechanism and machine theory, 46(12), 19801998.

[31] Jedliński, L., \&Jonak, J. (2012). Impact of selected errors in production and installation of bevel gear elements on total transmission error. ZeszytyNaukowe/AkademiaMorska w Szczecinie, 89-89.

[32] Wang, Z. Y., Zhai, H. M., \& Chen, H. (2013). Onmachine measurement of tooth profile errors of spiral bevel gears and its simulation. In Applied Mechanics and Materials (Vol. 394, pp. 245-250). Trans Tech Publications Ltd.

[33] Tetsu Nagata, Hayato Shichino, Yukio Tamura, Hitoshi Kawai, Yoriko Ohta, \&Masaharu Komori. (2013).Development of optimal tooth flank in spiral bevel gear by contact analysis and measurement. Komatsu technical report, 59(166), 2-8.

[34] Guo, C. H., Yang, W. T., Liu, Z. F., \& Zhang, Z. M. (2013). Tooth Contact Analysis and Transmission Error Optimization for Klingelnberg Spiral Bevel Gear. In Applied Mechanics and Materials (Vol. 310, pp. 323327). Trans Tech Publications Ltd.

[35] Shanmugasundaram, S., Kumaresan, M., \&Muthusamy, $N$. (2014). Effects of pressure angle and tip relief on the life of speed increasing gearbox: a case study. SpringerPlus, 3(1), 1-10.

[36] Lei, D. C., Tang, J. Y., \& Tang, J. J. (2014). Gear Dynamic Transmission Error Testing. In Advanced Materials Research(Vol. 871, pp. 352-357). Trans Tech Publications Ltd.

[37] Li, H., Wei, W., Liu, P., Kang, D., \& Zhang, S. (2014). The kinematic synthesis of involute spiral bevel gears and their tooth contact analysis. Mechanism and Machine Theory, 79, 141-157.
[38] Sanchez-Marin, F., Fuentes, A., Iserte, J. L., \& Gonzalez-Perez, I. (2014, August). A new geometrically adaptive approach for tooth contact analysis of gear drives. In International gear conference (pp. 486-494).

[39] Lin, C. H., \& Fong, Z. H. (2015). Numerical tooth contact analysis of a bevel gear set by using measured tooth geometry data. Mechanism and Machine Theory, 84, 1-24.

[40] Hepeng, X., Xiaozhong, D., \&Aijun, X. (2016). Meshing Performance Analysis of Spiral Bevel Gears Based on Assembly Misalignment.

[41] Ding, H., Tang, J., Zhong, J., \& Zhou, Z. (2016). A hybrid modification approach of machine-tool setting considering high tooth contact performance in spiral bevel and hypoid gears. Journal of Manufacturing Systems, 41, 228-238.

[42] Banodiya, B., \& Karma, V. K. (2017). Measurement of transmission error in spur gears. International Research Journal of Engineering and Technology, 4(8), 2369-2375.

[43] Hou, Y., Zhou, X., He, X., Liu, Z., \& Liu, Q. (2017, December). A New Design of the Test Rig to Measure the Transmission Error of Automobile Gearbox. In IOP Conference Series: Materials Science and Engineering (Vol. 280, No. 1, p. 012008). IOP Publishing.

[44] Tan, R., Chen, B., Liang, D., \& Peng, C. (2018). Theoretical and experimental analyses of spiral bevel gears with two contact paths. Proceedings of the Institution of Mechanical Engineers, Part C: Journal of Mechanical Engineering Science, 232(4), 665-676.

[45] Kučera, P., Pišstěk, V., Prokop, A., \&Řehák, K. (2018). Transmission error analysis for heavy-duty gearbox. Vibroengineering Procedia, 18, 113-116.

[46] Cai, Y., Yao, L., Ding, J., Ouyang, S., \& Zhang, J. (2019). Study on transmission error of double circular arc spiral bevel gears for nutation drive based on assembly errors and different loads. ForschungimIngenieurwesen, 83(3), 481-490.

[47] Yang, X., Song, C., Zhu, C., Liang, C., \& Sun, R. (2019). Impacts of misalignments on mesh behaviors of face-hobbed hypoid gear considering system deformation. IEEE Access, 7, 79244-79253.

[48] Sun, X., Zhao, Y., Liu, M., \& Liu, Y. (2019). On dynamic mesh force evaluation of spiral bevel gears. Shock and Vibration, 2019.

[49] Samani, F. S., Molaie, M., \&Pellicano, F. (2019). Nonlinear vibration of the spiral bevel gear with a novel tooth surface modification method. Meccanica, 54(7), 1071-1081.

[50] Narayanan, b. (2019). an optimal profile and lead modification in cylindrical gear tooth by reducing the load distribution factor

[51] Fu, Y., Zhuo, Y., Zhou, X., Wan, B., Lv, H., \& Wang, Z. (2020). Theoretical and experimental study on contact characteristics of spiral bevel gears under quasi-static 
Vol. 6, No. 11, 2021, PP. 21-29

\section{International Journal of Innovations in Engineering and Science, www.ijies.net}

and large loading conditions. Applied Sciences, 10(15), 5109.

[52] Mu, Y., Li, W., \& Fang, Z. (2020). Tooth surface modification method of face-milling spiral bevel gears with high contact ratio based on cutter blade profile correction. The International Journal of Advanced Manufacturing Technology, 106(7), 3229-3237.

[53] Peng, S., Ding, H., Tang, J., \& Zhou, Y. (2020). Collaborative machine tool settings compensation considering both tooth flank geometrical and physical performances for spiral bevel and hypoid gears. Journal of Manufacturing Processes, 54, 169 179.

[54] Kong, X., Ding, H., Huang, R., \& Tang, J. (2021). Adaptive data-driven modeling, prediction and optimal control for loaded transmission error of helicopter zerol spiral bevel gear transmission system. Mechanism and Machine Theory, 165, 104417.

[55] Mu, Y., He, X., \& Fang, Z. (2021). Multiobjective easeoff optimization of high-speed spiral bevel gear for loaded meshing performance. Journal of the Brazilian Society of Mechanical Sciences and Engineering, 43, 112. 